\title{
Antidiabetic and Antihypercholesterolemia Activities of Rambutan (Nephelium lappaceum L.) and Durian (Durio zibethinus Murr.) Fruit Peel Extracts
}

\author{
M. Muhtadi*, H. Haryoto, Tanti Azizah Sujono, Andi Suhendi \\ Pharmacy Faculty, Universitas Muhammadiyah Surakarta J1. A. Yani Tromol Pos I, Pabelan, Kartasura, Surakarta-57102, Indonesia.
}

\begin{tabular}{|c|c|}
\hline ARTICLE INFO & ABSTRACT \\
\hline Article history: & \multirow{11}{*}{$\begin{array}{l}\text { This research study aimed to explore the antidiabetic and antihypercholesterolemia activities of rambutan } \\
\text { (Nephelium lappaceum L.) and durian (Durio zibethinus Murr.) fruit peels extracts. Diabetic rats induced by } \\
\text { alloxan intra-peritoneal at dose } 150 \mathrm{mg} / \mathrm{kg} \text {.bw. Rats divided into eight groups, negative control received } 0.5 \% \\
\text { CMC-Na, Glibenclamide } 0.45 \mathrm{mg} / \mathrm{kg} \text {.bw (positive control), groups of III, IV, and V were given ethanolic } \\
\text { extracts of durian rind with successive doses of } 500,250,125 \mathrm{mg} / \mathrm{kg} . b w \text {, while groups of VI, VII and VIII were } \\
\text { given of rambutan peels extracts for } 11 \text { days. Whereas, antihypercholesterolemia activity, high cholesterol gained } \\
\text { by high-fat fed diet for } 28 \text { days and treated with the extracts for } 14 \text { days. The highest percentage reduction in } \\
\text { blood glucose and cholesterol levels were shown of rambutan fruit peels extract with dose } 500 \mathrm{mg} / \mathrm{kg} \text {.bw and the } \\
\text { value of percentage reduction were } 61.76 \pm 4.26 \% \text { and } 60.75 \pm 8.26 \% \text {, respectively which the activity were higher } \\
\text { than positive control. While the durian rind extract with dose } 500 \mathrm{mg} / \mathrm{kg} \text {.bw had showed the reduction glucose } \\
\text { levels at } 50.19 \pm 3.66 \% \text { and } 35.82 \pm 5.00 \% \text { for reduction cholesterol levels. Nephelium lappaceum and Durio } \\
\text { zibethinus peels extracts had the antidiabetic and antihypercholesterolemia activities at doses of } 125 \text { to } 500 \\
\text { mg/kg.bw. }\end{array}$} \\
\hline Received on: 18/10/2015 & \\
\hline Revised on: 17/12/2015 & \\
\hline Accepted on: 22/01/2016 & \\
\hline Available online: 30/04/2016 & \\
\hline Key words: & \\
\hline Rambutan (Nephelium & \\
\hline lappaceum L.), Durian & \\
\hline (Durio zibethinus Murr.), & \\
\hline antidiabetic, & \\
\hline antihypercholesterolemia. & \\
\hline
\end{tabular}

\section{INTRODUCTION}

Diabetes mellitus and hypercholesterolemia are degenerative diseases often found the case in Indonesia, and prevalence number show increasing trends each year. WHO (World Health Organization) and the IDF (International Diabetes Federation) predicts an increase in the prevalence of diabetes reaches 2-3 times in 2030, so a lot of research conducted to prevention and management of diabetes and its complications (PERKENI, 2011). While cholesterol is fatty deposits found in the blood vessels can cause constriction of blood vessels due to blood vessel walls become thicker and inelastic.

Cholesterol is normally produced by the body in the normal amounts. However, changes in eating patterns that formed of animal food and high fat, caused cholesterol levels in the blood increase. That condition is the major factor associated with atherosclerotic coronary heart disease which can lead to many deaths (Departemen Kesehatan, 2005).

\section{* Corresponding Author}

M. Muhtadi, Pharmacy Faculty, Universitas Muhammadiyah

Surakarta Central of Java, Indonesia.Email:muhtadi@ums.ac.id
The diseases therapy typically uses synthetic drugs during their lifetime. In contrary, long-term treatment such as diabetic and hypercholesterolemia had side effects such as water retention with hyponatremia, gastrointestinal disorders (Krentz and Bailey, 2005). The result is tendency of people today prefer natural remedies as a natural remedy due to lack of side effects, cheap and easier to find the raw materials in the surrounding community, compared to synthetic drugs (Lin, 2010). This phenomenon is of particular concern among the natural products researchers. In 1980 WHO recommended that an examination of the plant which had the effect of hypoglycemia due to the use of modern drugs that are less safe (Kumar et al, 2005). Previous study, showed that the ethanol extract of the durian fruit peels (Roongpisuthipong et al., 1991) and rambutan fruit peels (Manaharan et al., 2012) had as antihyperglycemic activity using in vitro model. Based on the research of Batubara (2011) of ethanol extract of the durian rind had high potential antioxidant activity. Durian had reported as an antioxidant and antiproliferative (Haruenkit et al., 2010). Polyphenols and flavonoids are active compounds which capable inhibiting the rise in plasma lipids and plasma antioxidant activity on Wistar rats burdened cholesterol (Leontowicz et al., 2011). 
Rambutan fruit peel contains flavonoids, tannins and saponins (Dalimartha, 2003). Ethanol extract of rambutan fruit peels contains ethyl gallate (Muhtadi, et al., 2014) which has the strong antioxidant activity, epigallocatechin-3-gallate (Palanisamy et al., 2011) as the potential antihyperglicemia (Waltner-Law et al., 2002) as well as powerful antioxidants (Tabata et al., 2008). Ethanol extract of rambutan fruit peels are known to have a greater ability as an antioxidant to capture DPPH free radicals than vitamin E (Tamimy, 2006). People with diabetes generally have high levels of oxidative stress as the effects of the imbalance between antioxidant protective and increased production of free radicals that can trigger complications. Therefore to prevent the complications in diabetic condition should be given antioxidants (Sujono and Sutrisna, 2010). Haruenkit et al. (2010) explains that the content of polyphenols, flavonoids, flavanols, ascorbic acid and tannin acts as an antioxidant. Polyphenols such as catechins can capture free radicals and reduce oxidative stress (Widowati, 2008).

This article describes the findings of research that had been conducted on antidiabetic and antihypercholesterolemic activities of rambutan (Nephelium lappaceum) and durian (Durio zibethinus) fruit peels in rats. The results of this study are expected to contribute both scientifically by obtaining scientific data of antihypercholesterolemic and antidiabetic activities and solutions to the problems of waste fruit peels and the utilization in traditional medicine in the community.

\section{MATERIALS AND METHODS}

\section{Plant material and extraction}

Durian (Durio zibethinus Murr.) and rambutan (Nephelium lappaceum Linn.) fruit peels were collected fresh from the waste fruit traders in the market areas in Surakarta, Central of Java, Indonesia and dried in the shade and then powdered. The plant was identified by expert team from the pharmaceutical biology, Pharmacy Faculty, Universitas Muhammadiyah Surakarta. The yield of extracts from the extraction of three times maceration was approximately $16.93 \%$ and $27.16 \%$, respectively.

\section{Experimental Animals}

Male albino rats of inbred Wistar strain (body wt. 150$300 \mathrm{~g}$ ) were used in this study. The animals were fed on a pellet diet and water ad libitum throughout the study period. All the experiments were carried out in between 8 and 10 A.M in order to avoid circadian rhythm induced changes. This study protocols were approved by Health Search Ethics Committee of Faculty of Medicine, Universitas Muhammadiyah Surakarta.

\section{Testing of Preclinical Antidiabetic}

Blood sampling was collected through the lateral vein in rats contained as much as $0.5 \mathrm{~mL}$ in the Eppendorf tubes, then centrifuged using mini spin for 20 minutes at 12,000 rpm to obtain the serum. Furthermore, the supernatant was taken using a micropipette inserted into as many as $10 \mathrm{uL}$ cuvettes then added
$1000 \mathrm{~mL}$ GOD-PAP reagent mixture and incubated for $10 \mathrm{~min}$ at $37{ }^{\circ} \mathrm{C}$. Then the absorbance of blank, standard and samples were determined using spectrophotometer at $\lambda 500 \mathrm{~nm}$.

Treatment of Diabetic-Induced Rats. The animals used for testing were randomly divided into 8 groups, each consisting of 5 rats. Each rat was fasted blood drawn previously used for 12-15 hours and measured blood glucose levels baseline. Furthermore, all groups induced by alloxan monohydrate intraperitoneally 150 $\mathrm{mg} / \mathrm{kg}$ (Lee et al., 2007). Four days after alloxan induced rats blood glucose levels were measured again, if there is an increase in blood glucose levels of rats up to $\pm 200 \mathrm{mg} / \mathrm{dL}$ was considered as diabetic rat. Then each group was treated as follows:

Group 1-Control: This group was used for studying the baseline values of the parameters studied.

Group 2-Diabetic control: This group consisted of glibenclamide induced diabetic rat with dose 0.45 $\mathrm{mg} / \mathrm{kg} . \mathrm{bw}$.

Group 3-Diabetic rats treated with (500 mg/kg.bw) ethanolic extract of durian rind.

Group 4-Diabetic rats treated with $(250 \mathrm{mg} / \mathrm{kg}$.bw) ethanolic extract of durian rind.

Group 5-Diabetic rats treated with (125 mg/kg.bw) ethnolic extract of durian rind.

Group 6- Diabetic rats treated with (500 mg/kg.bw)

ethnaolic extract of rambutan peel.

Group 7-Diabetic rats treated with (250 mg/kg.bw)

ethnaolic extract of rambutan peel.

Group 8-Diabetic rats treated with (125 mg/kg.bw)

ethnaolic extract of rambutan peel.

The treatment of the extract conducted for 15 days.

\section{Antihypercholesterolemic Condition Testing}

The rats were fed by high-fat diet for 28 days. High-fat diet was made consist of $50 \mathrm{~mL}$ of cooking oil, $10 \mathrm{~g}$ quail egg yolk, $0.1 \%$ PTU and water to $100.0 \mathrm{~mL}$ and other high-fat feed consist of $150 \mathrm{~g}$ standard feed (pellets), quail egg yolks $20 \mathrm{~g}$, and $50 \mathrm{~g}$ margarine. Drinking water $0.1 \%$ PTU with dose of $2 \mathrm{~mL} / 200$ g b.w. was administered and always made new.

Rats were divided into 8 groups. Each group consisted of 5 rats. All test animals first adapted to the standard and distilled water were fed ad libitum for 7 days. Before given the diet and a high-cholesterol feeding, the test animals were measured their total cholesterol levels. Then, they were given a high-fat diet for 4 weeks and treated with the extract for 2 weeks. Rat's blood samples of $1.5 \mathrm{~mL}$ were taken from the tail vein. High-fat feed were given as much as $30 \mathrm{~g}$ daily for 5 rats and high-fat diet with a dose of $2 \mathrm{~mL} / 200 \mathrm{~g}$ b.w, while the treatment of the extract conducted for 2 weeks (after hypercholesterolemia with total cholesterol levels $>150 \mathrm{mg} / \mathrm{dL}$ ) in all groups as below:

Group 1: $0.5 \%$ CMC-Na (negative control)

Group 2: Cholestyramine $0.8 \mathrm{~g} / \mathrm{kg}$ (positive control).

Group 3: Rambutan fruit peel extract dose of 500 $\mathrm{mg} / \mathrm{kg}$.bw daily. 
Group 4: Rambutan fruit peel extract dose of 250 $\mathrm{mg} / \mathrm{kg}$.bw daily.

Group 5: Rambutan fruit peel extract dose of 125 $\mathrm{mg} / \mathrm{kg}$.bw daily.

Group 6: Durian rind extract dose of $500 \mathrm{mg} / \mathrm{kg}$.bw daily.

Group 7: Durian rind extract dose of $250 \mathrm{mg} / \mathrm{kg} . \mathrm{bw}$ daily.

Group 8: Durian rind extract dose of $125 \mathrm{mg} / \mathrm{kg}$.bw daily.

\section{Statistical Analysis}

All data, blood glucose levels (mg/dL) and cholesterol levels $(\mathrm{mg} / \mathrm{dL})$ were expressed as mean $\pm \mathrm{SD}(\mathrm{n}=5)$. The data in post-treatment of extract were assessed by ShapiroWilk test to obtain the prevalence of normal distribution. Statistical differences between the groups (treated groups and control) were identified by using one-way ANOVA; degree of freedom was $\mathrm{p}<0.05$. If the test was significant, it was then followed by LSD post hoc test.

\section{RESULTS AND DISCUSSION}

The samples of fruit peels were extracted using cold maceration method with a mixture of ethanol 96\%:acetone (4:1). Sanjaya (2012) stated that the solvent mixture of ethanol and acetone can provide a good extract, because it was more selective, nontoxic, neutral, hot to less concentration, and ethanol can be mixed with acetone in all comparisons. The weight of durian rind extract obtained was 338.6 grams with a yield of $16.93 \%$. While rambutan fruit peel extract was 543.2 grams with a yield of $27.16 \%$. Alloxan is selectively toxic to pancreatic $\beta$ cells that produce insulin due to the accumulation of alloxan through the GLUT2 transporter. Toxic action of alloxan on $\beta$ cells is initiated by free radicals formed by redox reactions. In vitro assays known mechanisms of alloxan to the pancreatic $\beta$ cell destruction by inducing expenditure of the mitochondria calcium ions resulting in impaired cell oxidation process and result in disruption of homeostasis (Watkins et al., 2008). Animal tests with glucose \pm $200 \mathrm{mg} / \mathrm{dL}$ declared diabetes (Sunarsih et al., 2007). The results of the measurement of blood glucose levels during treatment of rats 7 days can be seen in Table 1. The cholesterol-lowering effect testing, which is used to determine the effect of the samples extracts in lowering cholesterol levels in the blood, was conducted in dosages with three different ratings. The positive control was treated with cholesteramine of $0.8 \mathrm{~g} / \mathrm{kg} . \mathrm{bw}$ daily. Based on Sujono and Sutrisna (2010) cholesteramine, which was given $0.8 \mathrm{~g} / \mathrm{kg}$.bw, reduced cholesterol levels by $52.97 \pm 1.12 \%$ on administered for 30 days. In this study, cholesteramine given for 14 days reduced the blood cholesterol by $34.20 \pm 10.48 \%$.

The CMC-Na $0.5 \%$ was used as a negative control, and it did not affect the blood cholesterol levels. The ethanolic extract of Nephelium lappaceum and Durio zibethinus fruit peels with dose of $500 \mathrm{mg} / \mathrm{kg} . \mathrm{bw}$ had antidiabetic activity stronger than Glibenclamide $0.45 \mathrm{mg} / \mathrm{kg}$.bw.

The sample's ability in lowering blood glucose levels due to contents of flavonoid and phenolic compounds. Presumed mechanism of action of flavonoids are by regenerate and stimulate the release of insulin by pancreatic $\beta$ cells (Dheer and Bhatnagar, 2010). There are three mechanisms of a decrease in blood glucose levels from the plant as a potential antidiabetic, namely: 1) the adstringen ability that can precipitate proteins intestinal mucous membrane and form a layer that protects the intestine, thereby inhibiting the intake of glucose, 2) accelerating the release of glucose from the circulation to expedite filtration and renal excretion, 3) accelerating the release of glucose by the increase in metabolism or enter into fatty deposits, which process involves the pancreas to produce insulin (Widowati, 2008).

Table 1: The mean of blood glucose levels of rats, baseline, pre- and post-treatment.

\begin{tabular}{|c|c|c|c|c|}
\hline \multirow{2}{*}{ Treatment } & \multicolumn{3}{|c|}{ Glucose levels (mg/dL) } & \multirow[b]{2}{*}{ Percentage of decreasing } \\
\hline & Baseline & Post alloxan & Post treatment of extract & \\
\hline Negative control (CMC-Na 0.5\%) & $79.60 \pm 22.01$ & $217.80 \pm 15.27$ & $227.80 \pm 21.58$ & - \\
\hline Positive control (Glibenclamide $0.45 \mathrm{mg} / \mathrm{kg} . \mathrm{bw}$ ) & $66.60 \pm 6.88$ & $213.60 \pm 13.94$ & $131.60 \pm 29.57$ & $41.90 \pm 13.05$ \\
\hline Rambutan fruit peel extract dose of $500 \mathrm{mg} / \mathrm{kg} . \mathrm{bw}$ & $113.80 \pm 8.70$ & $200.80 \pm 7.46$ & $86.60 \pm 9.63$ & $61.75 \pm 4.26$ \\
\hline Rambutan fruit peel extract dose of $250 \mathrm{mg} / \mathrm{kg} . \mathrm{bw}$ & $91.00 \pm 21.20$ & $250.80 \pm 26.88$ & $115.40 \pm 7.30$ & $49.05 \pm 3.22$ \\
\hline Rambutan fruit peel extract dose of $125 \mathrm{mg} / \mathrm{kg} . \mathrm{bw}$ & $74.20 \pm 9.15$ & $228.80 \pm 6.53$ & $171.20 \pm 5.89$ & $22.65 \pm 2.10$ \\
\hline Durian fruit peel extract dose of $500 \mathrm{mg} / \mathrm{kg} . \mathrm{bw}$ & $79.60 \pm 16.90$ & $237.20 \pm 14.06$ & $112.80 \pm 8.29$ & $50.19 \pm 3.66$ \\
\hline Durian fruit peel extract dose of $250 \mathrm{mg} / \mathrm{kg} . \mathrm{bw}$ & $104.40 \pm 9.21$ & $218.60 \pm 11.76$ & $147 \pm 8.69$ & $35.09 \pm 3.84$ \\
\hline Durian fruit peel extract dose of $125 \mathrm{mg} / \mathrm{kg} . \mathrm{bw}$ & $75.40 \pm 19.32$ & $225.20 \pm 14.30$ & $189 \pm 6.78$ & $16.55 \pm 2.99$ \\
\hline
\end{tabular}

Note: The experiment was carried out in triplicate.

Table 2: The mean cholesterol levels decrease after being given the extract.

\begin{tabular}{|c|c|c|c|c|}
\hline \multirow{2}{*}{ Treatment } & \multicolumn{4}{|c|}{ Cholesterol levels (mg/dL) } \\
\hline & Baseline & Induction for 28 days & After giving of extract & Decreasing levels (\%) \\
\hline Negative control (CMC-Na) & $61.00 \pm 11.87$ & $145.80 \pm 23.40$ & $126.60 \pm 32.17$ & $13.44 \pm 15.45$ \\
\hline Positive control (cholesteramine) & $58.60 \pm 4.16$ & $116.80 \pm 10.23$ & $77.20 \pm 16.02$ & $34.20 \pm 10.48$ \\
\hline Rambutan fruit peel extract dose of $500 \mathrm{mg} / \mathrm{kg} . \mathrm{bw}$ & $78.80 \pm 18.75$ & $203.20 \pm 43.41$ & $80.20 \pm 24.71$ & $60.75 \pm 8.26$ \\
\hline Rambutan fruit peel extract dose of $250 \mathrm{mg} / \mathrm{kg} . \mathrm{bw}$ & $62.20 \pm 5.36$ & $133.60 \pm 30.01$ & $88.20 \pm 15.64$ & $31.15 \pm 18.15$ \\
\hline Rambutan fruit peel extract dose of $125 \mathrm{mg} / \mathrm{kg} . \mathrm{bw}$ & $61.20 \pm 6.34$ & $180.20 \pm 12.68$ & $141.00 \pm 2.92$ & $21.39 \pm 6.61$ \\
\hline Durian fruit peel extract dose of $500 \mathrm{mg} / \mathrm{kg} . \mathrm{bw}$ & $64.40 \pm 13.40$ & $170.20 \pm 16.14$ & $109.40 \pm 15.79$ & $35.82 \pm 5.00$ \\
\hline Durian fruit peel extract dose of $250 \mathrm{mg} / \mathrm{kg} . \mathrm{bw}$ & $57.20 \pm 4.14$ & $131.80 \pm 12.59$ & $84.20 \pm 7.01$ & $35.79 \pm 6.63$ \\
\hline Durian fruit peel extract dose of $125 \mathrm{mg} / \mathrm{kg} . \mathrm{bw}$ & $52.00 \pm 4.47$ & $107.40 \pm 35.09$ & $92.40 \pm 21.45$ & $12.36 \pm 6.96$ \\
\hline
\end{tabular}

Note: The experiment was carried out in triplicate. 
Nephelium lappaceum fruit peel extract contains flavonoids, phenolics and tannins (Dalimartha, 2003), there are quercetin and geraniin (Palanisamy et al., 2011), ethyl gallate (Muhtadi et al., 2014), and epigallocatechin-3-gallate (EGCG), which has an activity antihyperglychemia (Waltner-Law et al., 2002), as powerful antioxidants (Tabata et al., 2008). Durio zibethinus had reported contains flavonoids, namely catechin and quercetin (Dembitsky et al., 2011) as well as polyphenols and tannins (Haruenkeit et al., 2010). Quercetin had activity Aldos reductase inhibitors that could potentially be used in therapeutic antihyperglycemia (Manaharan et al., 2011).

The content of flavonoids such as catechin, quercetin and EGCG, polyphenols and tannins, suspected that the mechanism of reduction in blood glucose levels in testing animals through the inhibition of glucose absorption stimulates the release of insulin and indirectly through a mechanism of antioxidant processes. Other reported mechanisms of decrease in blood glucose levels in testing animals, which was due to geraniin on rambutan fruit peel extract had the ability to prevent the formation of AGEs (Lee et al., 2007).

The some flavonoids such as hesperidin and naringin in citrus fruit peels had reported decreases the activities of glucose-6phospate and phosphoenol pyruvate. The antidiabetic potential of orange peel appears to be mediated via antiperoxidation, inhibition of $\alpha$-amylase enzyme activity that is responsible for the conversion of complex carbohydrates to glucose, increased hepatic glycogen content, stimulation of insulin secretion, and repair of secretory defects of pancreatic $\beta$-cells (Parmar and Kar, 2008).

Based on data of antihypercholesterolemia testing results in Table 2, Nephelium lappaceum fruit peel extract at a dose of $500 \mathrm{mg} / \mathrm{kg}$.bw had the strongest activity to reduce cholesterol levels in the blood of rats, which was $60.75 \%$ more powerful than the positive control (cholestyramine, a dose of $800 \mathrm{mg} / \mathrm{kg} . \mathrm{bw}$ ). This showed that the ethanol extract of Nephelium lappaceum fruit peel was very potent as the antihypercholesterolemia herbal medicine ingredient.

Based on the review of the literature has never reported the results of research and known exactly what compounds which act as lowering levels of cholesterol in the extract of rambutan peel, and also unknown pharmacological mechanism. In this study proved that the ethanol extract of Nephelium lappaceum and Durio zibethinus fruit peels were able to decrease the blood glucose and cholesterol levels of rats induced.

However, the mechanism of the antidiabetic and antihypercholesterol activities of the extracts of Nephelium lappaceum and Durio zibethinus fruit peels were not known certainly. It is necessary to test the molecular pharmacology to determine the mechanism of decrease in blood glucose levels that occurs. In addition it is necessary to ensure the active compound what is most responsible for its pharmacological activity.

\section{CONCLUSION}

Nephelium lappaceum and Durio zibethinus peels extracts had the antidiabetic and antihypercholesterolemia acitivities at doses of 125 to $500 \mathrm{mg} / \mathrm{kg}$.bw, whereas the highest antidiabetic and antihypercholesterolemia activities was indicated by Nephelium lappaceum peel extract with dose of $500 \mathrm{mg} / \mathrm{kg} . \mathrm{bw}$, and showed significant activities when comparable with the positive control.

\section{ACKNOWLEDGMENT}

The authors wish to thank Universitas Muhammadiyah Surakarta and Higher Education of Ministry of Education and Cultural Republic Indonesia for PUPT Research Grant Scheme for financial support.

\section{REFERENCES}

Batubara RW. Antioxidant Activity of Ethanol Extract of Durian (Durio zibethinus Murr) peels and their fractions with DPPH Method and Determination Levels of phenolic and flavonoid total (In bahasa Indonesia). Skripsi. Surakarta: Fakultas Farmasi Universitas Muhammadiyah Surakarta, 2011.

Dalimartha S. 2003. Atlas of Indonesian Medicinal Plants (In Bahasa Indonesia). $2^{\text {nd }}$ ed., Jakarta: Puspa Swara.

Dembitsky VM, Poovarodom S, Leontowicz H, Leontowicz M, Vearasilp S, Trakhtenberg S, et al. The multiple nutrition properties of some exotic fruits: Biological activity and active metabolites. Food Research International, 2011; 44(7): 1671-1701.

Departemen kesehatan, Pharmaceutical Care for Diabetes Mellitus (In Bahasa Indonesia) Jakarta: Departemen Kesehatan RI, 2005.

Dheer R, Bhatnagar P. A study of the Antidiabetic Activity of Barleria prionitis Linn., Indian Journal of Pharmacology, 2010; 42(2): 70-3.

Haruenkeit R, Poovarodom S, Vearasilp S, Namiesnik J, Sliwka-Kaszynka M, Park YS, et al. Comparison of Bioactive Compounds, Antioxidant and Antiproliferative Activities of Mon Thong Durian During Ripening. Food Chemistry, 2010; 118(3): 540-547.

Krentz A J, Bailey CJ. Oral Diabetic Agents Current Role in Type 2 Diabetes Melitus. Review Article, 2005; 65(3): 394- 403

Kumar E K, Ramesh A, Kasiviswanath R. Hypoglicemic and Antihyperglicemic Effect of Gmelina asiatica Linn. in Normal and in Alloxan Induced Diabetic Rats. Biol. Pharm. Bull., 2005; 28(4): 729-732.

Lee SK, Hwang JY, Song JH, Jo JR, Kim MJ, Kim ME, Kim JI. Inhibitory Activity of Euonymus alatus against alpha-glucocidase In vitro and In vivo. Nutrition Research and Practice, 2007; 1(3): 184-188.

Leontowicz $\mathrm{H}$, Leontowicz $M$, Jesion I, Bielecki W, Poovarodom S, Vearasilp S, et al. Positive effects of durian fruit at different stages of ripening on the hearts and livers of rats fed diets high in cholesterol. European Journal of Integrated Medicine, 2011; 3: 169-181.

Lin JS. An Alternative Treatment Of Hyperlipidemia With Red Yeast Rice: A Case Report, Journal of Medical Case Reports, 2010; 4(4): $1-3$.

Manaharan T, Palanisamy U D, Ming CH. Tropical Plant Extracts as Potential Antihyperglycemic Agents. Molecules, 2012; 17(5): 5915-5923.

Manaharan T, Teng LL, Appleton D, Ming CH, Masilamani T, Palanisamy UD. Antioxidant and antiglycemic potential of Peltophorum pterocarpum plant parts. Food Chemistry, 2011; 129(4): 1355-1362.

Muhtadi, Haryoto, Sujono TA, Suhendi A, Yen KH. Antioxidant and Chemical Constituents of Some Indonesian Fruit Peels. Medicinal Plants - International Journal of Phytomedicines and Related Industries, 2014; 6(1): 43-46.

Muhtadi, Primarianti AU, Sujono TA. Antidiabetic Activity of Durian (Durio zibethinus Murr.) and Rambutan (Nephelium lappaceum L.) Fruit Peels in Alloxan Diabetic Rats. Procedia Food Science, 2015; (3): 255-261

Parmar HS, Kar A. Medicinal values of fruit peels from Citrus sinensis, Punica granatum, and Musa paradisiaca with respect to 
alterations in tissue lipid peroxidation and serum concentration of glucose, insulin, and thyroid hormones. J. Med. Food., 2008; 11: 376-381.

Palanisamy U D, Ling LT, Manaharan T, Appleton D. Rapid Isolation of Geraniin From Nephelium lappaceum Rind Waste and it's Anti-Hyperglycemic activity. Food Chemistry, 2011; 127: 21-27.

PERKENI, Consensus Control and Prevention of Type 2 Diabetes Mellitus in Indonesia (In Bahasa Indonesia), Jakarta, 2011.

Roongpisuthipong C, Banphotkasem S, Komindr S, Tanphaichitr V. Postprandial Glucose and Insulin Responses to Various Tropical Fruits of Equivalent Carbohydrate Content in non-insulindependent Diabetes Melitus. Diabetes Research and Clinical Practice, 1991; 14(2): 123-131.

Sanjaya A. 2012. Preparation of food colouring powder From Suji leaves extract (pleomele angsutifolia) in soxhlet extraction and maceration (In Bahasa Indonesia). [ONLINE] Available at: http://lib.unnes.ac.id/12466. [Accessed 23 December 2013].

Sujono TA, Sutrisna EM. Effect of Time Pretreatment Routine Flavonoids on Hypoglycemic Effect Tolbutamide in Males Rats Alloxan Induced (In Bahasa Indonesia). Jurnal Penelitian Sains dan Teknologi, 2010; 11(2): 94, 97.

Sunarsih SE, Djatmika, Utomo RS. Effect of infusion Gadung tuber (Dioscorea hispida Dennst) to decrease blood glucose levels of male rats of diabetic alloxan-induced (In Bahasa Indonesia). Majalah Farmasi Indonesia, 2007; 18(1): 32.
Tabata H, Katsube T, Tsuma T, Ohta Y, Imawaka N, Utsumi T. Isolation and evaluation of the radical-scavenging activity of the antioxidants in the leaves of an edible plant Mallotus japonicas. Food Chemistry, 2008; 109(1): 64-71.

Tamimy. Antioxidant Activity of Ethanol Extract of Rambutan (Nephellium lappaceum L.) Fruit Peel Against DPPH Free Radical Suppression by Spectrophotometer (In Bahasa Indonesia). Yogyakarta. 2006.

Waltner-Law M E, Wang XL, Law BK, Hall RK, Nawano M. Epigallocatechin gallate, a constituent of Green tea represses hepatic glucose production. J. Bio. Chem., 2002; 277(38): 34933-34940.

Widowati W. Antioxidants as Potential Antidiabetic (In Bahasa Indonesia). Jurnal Kesehatan Masyarakat, 2008; 7(2): 2-7.

\section{How to cite this article:}

Muhtadi M., Haryoto H., Tanti Azizah Sujono, Andi Suhendi. Antidiabetic and Antihypercholesterolemia Activities of Rambutan (Nephelium lappaceum L.) and Durian (Durio zibethinus Murr.) Fruit Peel Extracts. J App Pharm Sci, 2016; 6 (04): 190-194. 